\title{
Impact of Revised Code NBC105 on Assessment and Design of Low Rise Reinforced Concrete Buildings in Nepal
}

\author{
Jagat K. Shrestha a , Nirajan Paudel, Bishal Koirala, Binod R. Giri, Aadarsha Lamichhane \\ Department of Civil Engineering, Pulchowk Campus, Institute of Engineering, Tribhuvan University, Lalitpur, Nepal \\ Corresponding Author: a jagatshrestha@ioe.edu.np
}

Received: 2020-07-24

Revised: 2021-01-29

Accepted: 2021-02-19

\begin{abstract}
:
Gorkha Earthquake in 2015 has impacted considerably in the design and construction of buildings in Nepal. Strength and Safety of life and constructions have become the prime concerns of the government and the public. Regulation is required to achieve the strength and safety in the constructions. Hence, a need for revision of building codes has been felt and Nepal Building Code, NBC105 has been revised. This paper presents the impact of the revised code on seismic load estimation for low rise reinforced concrete buildings. For the assessment of the impact linear and non- linear static and linear dynamic analysis of reinforced concrete residential buildings of two storey and four Storey has been taken subjected to Indian Standard Codes IS 1893: 2002, IS 1893: 2016, Nepal Building Codes NBC 105: 1994 and NBC 105: 2020. The buildings were modeled and analyzed in SAP2000. The response of the buildings such as time period, base shear, drifts, and storey forces from the application of the four codes was compared. The comparison of the results shows that the structural response of the building under the revised NBC105:2020 is $60 \%$ to $65 \%$ higher compared to the previous code NBC105:1994
\end{abstract}

Keywords: NBC 105, IS 1893, Linear Analysis, Pushover Analysis

\section{Introduction}

Reinforced concrete construction increased drastically over the last few decades in the Kathmandu valley and other major urban centers in Nepal to meet the rapidly increasing settlement of the region. RC construction commenced around four decades ago as an alternative to traditional unreinforced masonry (URM) buildings that lack structural integrity and ductility. According to the National Census of 2011, about $10 \%$ of building construction in Nepal is RC, with more than $40 \%$ of the total RC construction being concentrated in the Kathmandu valley.

The seismic codes are prepared with consideration of seismology of country, accepted level of seismic risk, properties of construction materials, construction methods, and structure categories. Furthermore, the provisions given in seismic codes are based on the observations, experiments \& analytical case studies made during past earthquakes in particular region. In India, IS 1893 (Part 1) "Criteria for Earthquake Resistant Design of Structures" [1, 2], whereas in
Nepal, NBC 105 "Seismic Design of Building in Nepal" $[3,4]$ is used as code of practice for analysis \& designing of earthquake resistant buildings. Previously IS 1893: 2002 [1] was used as a governing code for the seismic resistant design of structures in Nepal. Considering the progressive study in the field of earthquake resistant design resulted the revision of IS 1893: 2002[1] in 2016 and thus a new seismic resistant design code in the form of IS 1893:2016 was developed. Nepal on the other hand had its own NBC 105: 1994 [3] as a governing code for the design of seismic resistant buildings in Nepal. NBC 105 [4, 3] was deemed to be just sufficient for the time being, but due to recent catastrophic Gorkha earthquake and recent advances in the field of seismic designs, the limitations and inadequacy in the NBC105 [3, 4] were exposed. Considering the above facts, a draft of the new updated code has been proposed as NBC 105:2020 [4]. Many codal provisions have been revised and many provisions regarding modal response spectrum method, elastic time history analysis, non- linear static and dynamic analysis, cracked stiffness of the members 
have been introduced in NBC 105: 2020 [4].

\section{Need of Research}

Before the introduction of Nepal National Building Code in 1994 AD [3], structural design of RC buildings in Nepal used to be done by referring Indian Standards. Such reference was relevant as well given the fact that Nepal borders India in three directions, thus, the design response spectrum and the diversity of soil type incorporated in Indian seismic design code IS 1893: 2002 [1] would reasonably be applicable for Nepal. After 1994, the seismic design code of Nepal NBC 105: 1994 [3] started to come in practice. Since there was no restriction in the use of Indian Standards [1,2] in the government level itself, even after the introduction of Nepali Standards [3, 4], the Indian code [1, 2] was equally popular. Even as of now, the compliance of one code would sufficiently ratify earthquake resistant design; hence depending upon the designer's expertise, both codes are widely used and accepted. As the building code compliance got implemented more stringently specially in the Kathmandu valley in the past decade, the awareness and understanding towards building codes grew among engineers. With it, emerged a new line of belief that Indian seismic code is more conservative than Nepali seismic code [3,4]. The design basis of Indian Standard Codes [1, 2] for seismic hazard analysis is deterministic approach whereas Nepal Building Code [3, 4] is based on probabilistic approach and a study on impact of revised code is necessary.

\section{Modeling and Analysis of Reinforced Concrete Building}

The building taken is two storey and staircase cover and four storey and staircase cover with cement sand as mortar and brick masonry infill wall. The total builtup area of the building is $891 \mathrm{sq}$. ft, consisting four full functional rooms and two partial functional room used for passage as well in each floor, as shown in Figure 1. In our analysis, we have considered brick masonry infill as unit. There are total 8 windows of size $5^{\prime} \times 5^{\prime}$, 1 window for staircase running from top storey to half of bottom storey a main entrance door of size $5^{\prime} \times 7^{\prime}$ and 4 door of size $3^{\prime} \times 7^{\prime}$. The thickness of the wall is provided to be $100 \mathrm{~mm}$ for partition and $230 \mathrm{~mm}$ for outer wall with brick properly bonded with cement sand mortar. The analysis of the building was carried out under different load combinations defined by different codes and compared the results as described in the following sections.

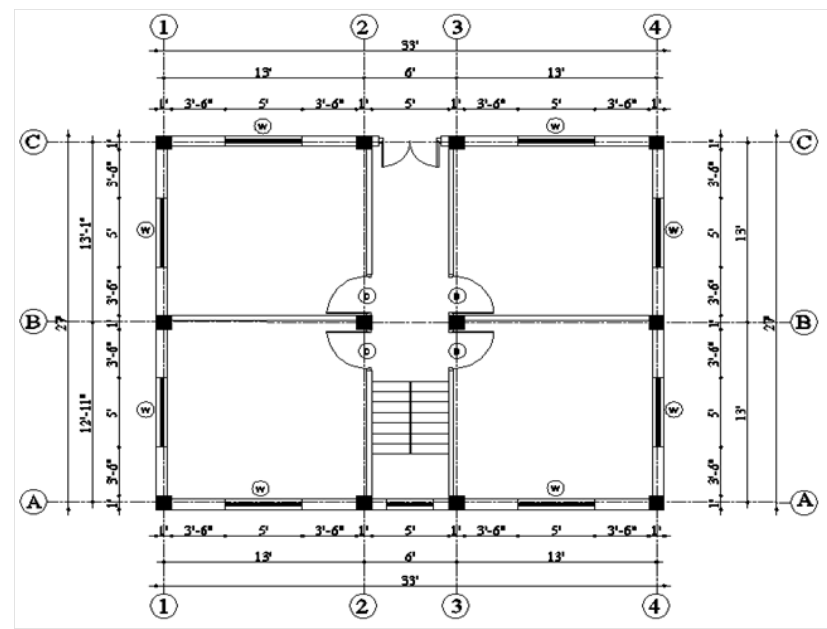

Figure 1: Typical Floor Plan of Building

\subsection{Material Property and Section Property}

Concrete is not an isotropic material. However, typical structural elements has a smaller dimension (width) and are considered isotropic for the purposes of structural calculations and design without much difference in results in macro scale analysis. So, the material used is assumed to be isotropic and homogeneous. The values used for the analysis are tabulated in Table 1.

Table 1: Material Property

\begin{tabular}{lc}
\hline Material & Property Value \\
\hline Characteristic strength of concrete $\left(\mathrm{f}_{\mathrm{ck}}\right)$ & $20 \mathrm{MPa}$ \\
Yield Strength of rebar $\left(\mathrm{f}_{\mathrm{y}}\right)$ & $500 \mathrm{MPa}$ \\
Specific unit weight of Brick Masonry $\left(\gamma_{b}\right)$ & $20 \mathrm{KN} / \mathrm{m}^{3}$ \\
Specific unit weight of reinforced concrete $\left(\gamma_{c}\right)$ & $25 \mathrm{KN} / \mathrm{m}^{3}$ \\
\hline
\end{tabular}

The section properties during modeling and analysis of two storey building and four storey building are tabulated in Table 2. The sizes of sections are based on the construction practice in four storey building.

Table 2: Section Properties

\begin{tabular}{lc}
\hline Section & Size \\
\hline Column & $300 \mathrm{~mm} \times 300 \mathrm{~mm}$ \\
Beam & $230 \mathrm{~mm} \times 350 \mathrm{~mm}$ \\
Slab & $125 \mathrm{~mm}$ \\
External Walls & $230 \mathrm{~mm}$ \\
Partition Walls & $110 \mathrm{~mm}$ \\
\hline
\end{tabular}




\subsection{Linear Static Analysis and Result Interpretation}

The linear static analysis of the building was carried out under different load combinations defined by different codes. For the Linear static analysis, SAP2000 was used as FEM tool. The column and beam were modeled as frame structure and floor slab was modeled as thin shell. A floor finish load of $1.15 \mathrm{KN} / \mathrm{m}^{2}$ was considered to account for the weight of floor finish while a live load of $2 \mathrm{KN} / \mathrm{m}^{2}$ was applied on floor slab of room and live load of $3 \mathrm{KN} / \mathrm{m}^{2}$ was applied on passage, staircase and balcony. Also, Live load of 1.5 was applied on the open terrace. Similar type of load was applied on both the buildings.

The seismic weight of the building was calculated according to the codal provision. SAP 2000 is not programmed for analyzing the structure based on National Nepal Building Code[3, 4] so, manual calculation for base shear according to NBC 105: 1994[3] and NBC 105: 2020[4] was calculated. Results obtained from analysis of both buildings in SAP 2000 are tabulated.

Base shear obtained from IS 1893: 2002[1], IS 1893: 2016 [2] and NBC 105: 1994 [3] are almost same as their horizontal acceleration coefficient value remain almost equal. While, for the NBC 105: 2020 the result is almost $60 \%$ more as shown in Table 3 . The variation in the result is due to the consideration of overstrength factor and ductility factor introduced in base shear coefficient. Also, due to the fact that new soil category has been introduced as Very soft soil (Soil Type D) in NBC 105: 2020 [4] to represent very soft soil found in Kathmandu valley core which is used for analyzing the structure in this report.

Time period obtained from IS 1893: 2002[1], IS 1893: 2016 [2] and NBC 105: 1994 [3] are almost same. While, for the NBC 105: 2020[4] the result is $25 \%$ more as shown in Table 4. The variation in the result can be attributed to the amplification factor introduced in approximation of time period.

Maximum Lateral Displacement along $\mathrm{x}$ - direction and y- direction obtained from IS 1893: 2002[1], IS 1893: 2016 [2] and NBC 105: 1994 [3] are almost same. While, for the NBC 105: 2020[4] the result is double the result from other codes as shown in Table 5 and Table 6 respectively. The variation in the result is due to difference in distribution of storey forces based on NBC and IS codes.
Table 3: Base Shear (in KN)

\begin{tabular}{lcc}
\hline CODES & $\begin{array}{c}\text { 2 Storey } \\
\text { With } \\
\text { Staircase Cover }\end{array}$ & $\begin{array}{c}\text { 4 Storey } \\
\text { With } \\
\text { Staircase Cover }\end{array}$ \\
\hline IS 1893:2002 & 169.778 & 348.809 \\
IS 1893:2016 & 169.770 & 348.809 \\
NBC 105:1994 & 163.782 & 320.348 \\
NBC 105:2020 & 270.279 & 528.978 \\
\hline
\end{tabular}

Table 4: Time Period (in Seconds)

\begin{tabular}{lcc}
\hline CODES & $\begin{array}{c}\text { 2 Storey } \\
\text { With } \\
\text { Staircase Cover }\end{array}$ & $\begin{array}{c}\text { 4 Storey } \\
\text { With } \\
\text { Staircase Cover }\end{array}$ \\
\hline IS 1893:2002 & 0.377 & 0.553 \\
IS 1893:2016 & 0.377 & 0.553 \\
NBC 105:1994 & 0.302 & 0.442 \\
NBC 105:2020 & 0.471 & 0.691 \\
\hline
\end{tabular}

Table 5: Maximum Lateral Displacement in X- Direction (in $\mathrm{mm}$ )

\begin{tabular}{lcc}
\hline CODES & $\begin{array}{c}\text { 2 Storey } \\
\text { With } \\
\text { Staircase Cover }\end{array}$ & $\begin{array}{c}\text { 4 Storey } \\
\text { With } \\
\text { Staircase Cover }\end{array}$ \\
\hline IS 1893:2002 & 5.668 & 20.073 \\
IS 1893:2016 & 5.661 & 20.044 \\
NBC 105:1994 & 5.733 & 18.134 \\
NBC 105:2020 & 9.445 & 30.157 \\
\hline
\end{tabular}

Table 6: Maximum Lateral Displacement in Y- Direction

\begin{tabular}{lcc}
\hline CODES & $\begin{array}{c}\text { 2 Storey } \\
\text { With } \\
\text { Staircase Cover }\end{array}$ & $\begin{array}{c}\text { 4 Storey } \\
\text { With } \\
\text { Staircase Cover }\end{array}$ \\
\hline IS 1893:2002 & 6.506 & 21.833 \\
IS 1893:2016 & 6.506 & 21.833 \\
NBC 105:1994 & 6.471 & 19.779 \\
NBC 105:2020 & 10.659 & 42.318 \\
\hline
\end{tabular}

Maximum storey drift along $\mathrm{x}$ - direction and $\mathrm{y}$ - direction obtained from IS 1893: 2002[1], IS 1893: 2016 [2] and NBC 105: 1994 [3] are almost same. While, for the NBC 105: 2020[4] the result is about 59\% to $65 \%$ more as shown in Table 7 and Table 8 respectively.

Maximum storey force along $\mathrm{x}$ - direction and $\mathrm{y}$ direction obtained from IS 1893: 2002[1], IS 1893: 2016 [2] and NBC 105: 1994 [3] are almost same. While, for the NBC 105: 2020[4] the result is about $60 \%$ to $65 \%$ more as shown in Table 9 and Table 10 respectively. 
Table 7: Maximum Storey Drift in X- Direction (in \%)

\begin{tabular}{|c|c|c|c|c|c|c|c|c|}
\hline CODES $\rightarrow$ & \multicolumn{2}{|c|}{ IS 1893:2002 } & \multicolumn{2}{c|}{ IS 1893:2016 } & \multicolumn{2}{c|}{ NBC 105:1994 } & \multicolumn{2}{c|}{ NBC 105:2020 } \\
\hline \multirow{3}{*}{ STOREY } & $\begin{array}{c}2 \text { Storey } \\
\text { with } \\
\text { Staircase } \\
\text { cover }\end{array}$ & $\begin{array}{c}\text { 4 Storey } \\
\text { With } \\
\text { Staircase } \\
\text { Cover }\end{array}$ & $\begin{array}{c}\text { 2 Storey } \\
\text { with } \\
\text { Staircase } \\
\text { cover }\end{array}$ & $\begin{array}{c}\text { 4 Storey } \\
\text { With } \\
\text { Staircase } \\
\text { Cover }\end{array}$ & $\begin{array}{c}\text { Storey } \\
\text { with } \\
\text { Staircase } \\
\text { cover }\end{array}$ & $\begin{array}{c}\text { 4 Storey } \\
\text { With } \\
\text { Staircase } \\
\text { Cover }\end{array}$ & $\begin{array}{c}\text { Storey } \\
\text { with } \\
\text { Staircase } \\
\text { cover }\end{array}$ & $\begin{array}{c}\text { Storey } \\
\text { With } \\
\text { Staircase } \\
\text { Cover }\end{array}$ \\
\hline 5 & & 0.0941 & & 0.0940 & & 0.0986 & & 0.1626 \\
\hline 4 & & 0.1145 & & 0.1143 & & 0.0997 & & 0.1680 \\
\hline 3 & 0.0636 & 0.1806 & 0.0636 & 0.1806 & 0.0710 & 0.1615 & 0.1167 & 0.2704 \\
\hline 2 & 0.0723 & 0.2084 & 0.0722 & 0.2084 & 0.0703 & 0.1999 & 0.1160 & 0.3315 \\
\hline 1 & 0.0692 & 0.1564 & 0.0691 & 0.1561 & 0.0733 & 0.1577 & 0.1210 & 0.2593 \\
\hline
\end{tabular}

Table 8: Maximum Storey Drift in Y- Direction (in \%)

\begin{tabular}{|c|c|c|c|c|c|c|c|c|}
\hline CODES $\rightarrow$ & \multicolumn{2}{|c|}{ IS 1893:2002 } & \multicolumn{2}{c|}{ IS 1893:2016 } & \multicolumn{2}{c|}{ NBC 105:1994 } & \multicolumn{2}{c|}{ NBC 105:2020 } \\
\hline \multirow{3}{*}{ STOREY } & $\begin{array}{c}2 \text { Storey } \\
\text { with } \\
\text { Staircase } \\
\text { cover }\end{array}$ & $\begin{array}{c}\text { 4 Storey } \\
\text { With } \\
\text { Staircase } \\
\text { Cover }\end{array}$ & $\begin{array}{c}\text { 2 Storey } \\
\text { with } \\
\text { Staircase } \\
\text { cover }\end{array}$ & $\begin{array}{c}\text { 4 Storey } \\
\text { With } \\
\text { Staircase } \\
\text { Cover }\end{array}$ & $\begin{array}{c}\text { Storey } \\
\text { with } \\
\text { Staircase } \\
\text { cover }\end{array}$ & $\begin{array}{c}\text { S Storey } \\
\text { With } \\
\text { Staircase } \\
\text { Cover }\end{array}$ & $\begin{array}{c}\text { Storey } \\
\text { with } \\
\text { Staircase } \\
\text { cover }\end{array}$ & $\begin{array}{c}\text { Storey } \\
\text { With } \\
\text { Staircase } \\
\text { Cover }\end{array}$ \\
\hline 5 & & 0.0892 & & 0.0892 & & 0.0941 & & 0.4148 \\
\hline 4 & & 0.1196 & & 0.1196 & & 0.1068 & & 0.2457 \\
\hline 3 & 0.0712 & 0.1824 & 0.0712 & 0.1824 & 0.0759 & 0.1660 & 0.1248 & 0.3045 \\
\hline 2 & 0.0792 & 0.2087 & 0.0792 & 0.2086 & 0.0784 & 0.2039 & 0.1293 & 0.3274 \\
\hline 1 & 0.0767 & 0.1641 & 0.0767 & 0.1642 & 0.0810 & 0.1665 & 0.1337 & 0.2449 \\
\hline
\end{tabular}

Table 9: Maximum Storey Force in X-Direction

\begin{tabular}{|c|c|c|c|c|c|c|c|c|}
\hline CODES $\rightarrow$ & \multicolumn{2}{|c|}{ IS 1893:2002 } & \multicolumn{2}{c|}{ IS 1893:2016 } & \multicolumn{2}{c|}{ NBC 105:1994 } & \multicolumn{2}{c|}{ NBC 105:2020 } \\
\hline \multirow{3}{*}{ STOREY } & $\begin{array}{c}2 \text { Storey } \\
\text { with } \\
\text { Staircase } \\
\text { cover }\end{array}$ & $\begin{array}{c}\text { 4 Storey } \\
\text { With } \\
\text { Staircase } \\
\text { Cover }\end{array}$ & $\begin{array}{c}\text { 2 Storey } \\
\text { with } \\
\text { Staircase } \\
\text { cover }\end{array}$ & $\begin{array}{c}\text { 4 Storey } \\
\text { With } \\
\text { Staircase } \\
\text { Cover }\end{array}$ & $\begin{array}{c}\text { 2 Storey } \\
\text { with } \\
\text { Staircase } \\
\text { cover }\end{array}$ & $\begin{array}{c}\text { 4 Storey } \\
\text { With } \\
\text { Staircase } \\
\text { Cover }\end{array}$ & $\begin{array}{c}\text { Storey } \\
\text { with } \\
\text { Staircase } \\
\text { cover }\end{array}$ & $\begin{array}{c}\text { 4 Storey } \\
\text { With } \\
\text { Staircase } \\
\text { Cover }\end{array}$ \\
\hline 5 & & 28.432 & & 28.432 & & 33.269 & & 57.469 \\
\hline 4 & & 147.375 & & 147.375 & & 105.555 & & 179.542 \\
\hline 3 & 29.237 & 111.215 & 29.237 & 111.215 & 31.743 & 90.762 & 52.117 & 150.384 \\
\hline 2 & 105.242 & 49.429 & 105.242 & 49.429 & 83.928 & 60.508 & 138.608 & 96.448 \\
\hline 1 & 35.298 & 12.357 & 35.298 & 12.357 & 48.111 & 30.254 & 79.554 & 45.135 \\
\hline
\end{tabular}

Table 10: Maximum Storey Force in Y- Direction

\begin{tabular}{|c|c|c|c|c|c|c|c|c|}
\hline CODES $\rightarrow$ & \multicolumn{2}{|c|}{ IS 1893:2002 } & \multicolumn{2}{c|}{ IS 1893:2016 } & \multicolumn{2}{c|}{ NBC 105:1994 } & \multicolumn{2}{c|}{ NBC 105:2020 } \\
\hline \multirow{3}{*}{ STOREY } & $\begin{array}{c}\text { 2 Storey } \\
\text { with } \\
\text { Staircase } \\
\text { cover }\end{array}$ & $\begin{array}{c}\text { 4 Storey } \\
\text { With } \\
\text { Staircase } \\
\text { Cover }\end{array}$ & $\begin{array}{c}\text { 2 Storey } \\
\text { with } \\
\text { Staircase } \\
\text { cover }\end{array}$ & $\begin{array}{c}\text { 4 Storey } \\
\text { With } \\
\text { Staircase } \\
\text { Cover }\end{array}$ & $\begin{array}{c}\text { 2 Storey } \\
\text { with } \\
\text { Staircase } \\
\text { cover }\end{array}$ & $\begin{array}{c}\text { 4 Storey } \\
\text { With } \\
\text { Staircase } \\
\text { Cover }\end{array}$ & $\begin{array}{c}\text { 2 Storey } \\
\text { with } \\
\text { Staircase } \\
\text { cover }\end{array}$ & $\begin{array}{c}\text { Storey } \\
\text { With } \\
\text { Staircase } \\
\text { Cover }\end{array}$ \\
\hline 5 & & 28.432 & & 28.432 & & 33.269 & & 57.469 \\
\hline 4 & & 147.375 & & 147.375 & & 105.555 & & 179.542 \\
\hline 3 & 29.237 & 111.215 & 29.237 & 111.215 & 31.743 & 90.762 & 52.117 & 150.384 \\
\hline 2 & 105.242 & 49.429 & 105.242 & 49.429 & 83.928 & 60.508 & 138.608 & 96.448 \\
\hline 1 & 35.298 & 12.357 & 35.298 & 12.357 & 48.111 & 30.254 & 79.554 & 45.135 \\
\hline
\end{tabular}


Many factors such as site condition, construction practice, used materials, workmanship, etc, play vital role in determining the seismic demands on the structural members of an RC building. The findings outline the lack of harmony between the two codes. Major differences and inconsistencies in the end results of the two codes developed by experts in the field of seismicity and structural design of each country, have created room for uncertainty especially when the subject being dealt is quite unpredictable, so the structural engineers should not just stick to code compliance but should start designing more resilient, redundant, collapse preventive and better performing structures in future. The comparison of results from different codes and revisions shows the revised codes have become more conservative to consider the uncertainties in estimation of seismic effects.

\section{Conclusion}

The design basis of Indian Standard Codes for seismic hazard analysis is deterministic approach whereas Nepal Building Code is based on probabilistic approach and impact of revised code is has been studied. The response of the buildings such as time period, base shear, drifts, and storey forces from the application of the four codes was compared in this study. The comparison of the results concludes that the base shear of the building under the revised NBC105:2020 is 60\% higher compared to the previous code NBC105:1994.

\section{References}

[1] Criteria for Earthquake resistant design of structures. Part 1 General Provisions and building, IS 1893:2002. Bureau of Indian Standard, New Delhi, India, 2002.

[2] Criteria for Earthquake resistant design of structures. Part 1 General Provisions and building, IS 1893: 2016. Bureau of Indian Standard, New Delhi, India, 2016.

[3] Seismic Design of Buildings in Nepal, NBC 105:1994. Department of Urban Development and Building Construction, Kathmandu, Nepal, 1994.

[4] Seismic Design of Buildings in Nepal, NBC 105: 2020. Department of Urban Development and Building Construction, Kathmandu, Nepal, 2020.

[5] Ready to use guideline for detailing of low Rise Reinforced Concrete Buildings without Masonry Infill, NBC 205:2012. Department of Urban Development and Building Construction, Kathmandu, Nepal, 2012. 
